\title{
The Effect of Neuro-Linguistic Programming on Depression, Anxiety and Stress in Liver Transplant Patients
}

\section{Karaciğer Nakli Hastalarında Nörolinguistik Programlamanın Depresyon, Anksiyete, Stres Üzerine Etkisi}

\author{
@Runida Doğan', @Aysel Doğan², @Nazlıcan Bağci ${ }^{3}$ \\ I'Inönü University, Faculty of Nursing, Malatya, Turkey \\ ${ }^{2}$ Toros University Faculty of Health Sciences, Department of Nursing, Mersin, Turkey \\ ${ }^{3}$ Doğanşehir Şehit Esra Köse Başaran State Hospital \\ Copyright@Author(s) - Available online at www.dergipark.org.tr/tr/pub/medr \\ Content of this journal is licensed under a Creative Commons Attribution-NonCommercial 4.0 International License.
}

\begin{abstract}
Aim: This study was conducted using a prospective randomized single-blind clinical trial model to examine the effect of neurolinguistic programming (NLP) on depression, anxiety, and stress in liver transplant patients.

Materials and Methods: This study was conducted with liver transplant patients at a university's Liver Transplant Institute between June 2021 and December 2021. The sample size of the study was determined as 84 (Experimental group: 42, control group: 42). Personal information form and Depression, Anxiety, and Stress Scale (DASS-21) were used to collect data. The data obtained from the research were evaluated with SPSS 25.

Results: In the experimental group, the mean score of DASS-21 was found to be $38.95 \pm 11.96$ before the NLP application and $25.21 \pm$ 5.43 after the NLP application. It was found statistically significant that the value obtained in the second measurement was lower than the value obtained in the first measurement $(p<0.05)$. It was determined that NLP application significantly decreased all parameters of depression, anxiety, and stress $(p<0.05)$. In the control group, the mean score of DASS-21 was determined as $51.05 \pm 7.53$ in the first measurement and $52.57 \pm 7.92$ in the second measurement. It was found statistically significant that the value obtained in the second measurement was higher than the value obtained in the first measurement $(p<0.05)$.

Conclusion: This study found that NLP reduced depression, anxiety, and stress in liver transplant patients. In line with this result, it can be suggested that nurse's benefit from NLP practice and receive training on NLP in managing the depression, anxiety, and stress experienced by liver transplant patients.
\end{abstract}

Keywords: Anxiety, depression, liver transplantation, neuro-linguistic programming, stress

Öz

Amaç: Bu araştırma karaciğer nakli olmuş hastalarda nörolinguistik programlamanın (NLP) depresyon, anksiyete ve stres üzerine etkisini incelemek amacı ile prospektif randomize tek kör klinik araştırma modeli kullanılarak gerçekleştirildi.

Materyal ve Metot: Araştırma; Bir üniversiteye ait Karaciğer Nakli Enstitüsünde karaciğer nakli olan hastalarla, Haziran 2021-Aralık 2021 tarihleri arasında gerçekleştirildi. Araştırmanın örneklem büyüklüğü 84 (Deney grubu:42, kontrol grubu:42) olarak belirlendi. Verilerin toplanmasında Kişisel Bilgi Formu ve Depresyon Anksiyete Stres Ölçeği (DASS- 21) kullanıldı. Araştırmadan elde edilen veriler SPSS 25. ile değerlendirildi.

Bulgular. Deney grubunda DASS-21 puan ortalaması NLP uygulamasından önce $38.95 \pm 11.96$, NLP uygulamasından sonra $25.21 \pm$ 5.43 olarak bulundu. İkinci ölçümde elde edilen değerin birinci ölçümde elde edilen değerden düşük olması istatistiksel olarak önemli bulundu $(p<0.05)$. NLP'nin depresyon, anksiyete ve stres parametrelerinin tamamını önemli düzeyde düşürdüğü saptandı ( $p<0.05)$. Kontrol grubunda DASS-21 puan ortalaması ilk ölçüm $51.05 \pm 7.53$, ikinci ölçüm $52.57 \pm 7.92$ olarak belirlendi. İkinci ölçümde elde edilen değerin birinci ölçümde elde edilen değerden yüksek olması istatistiksel olarak önemli bulundu $(p<0.05)$.

Sonuç ve Öneriler. Araştırmada NLP'nin karaciğer nakli olmuş hastalarda depresyon, anksiyete ve stresi azalttığı bulundu. Bu sonuç doğrultusunda hemşirelerin karaciğer nakli hastalarının yaşadığı depresyon, anksiyete ve stresi yönetmede NLP uygulamasından faydalanması ve bu konuda eğitimler alması önerilebilir.

Anahtar kelimeler. Anksiyete, depresyon, karaciğer nakli, nörolinguistik programlama, stres

Geliş Tarihi / Received: 03.12.2021 Kabul Tarihi / Accepted: 20.12.2021

Sorumlu Yazar /Corresponding Author. Runida Doğan, İnönü University, Faculty of Nursing, Malatya, Turkey,

E-mail: runidademir@hotmail.com 


\section{INTRODUCTION}

Liver transplantation is accepted as the most effective method in the treatment of end-stage liver disease (1). Improvements in immunosuppressive therapy and surgical methods have led to the increasing preference of liver transplantation $(2,3)$. Although liver transplantation increasesthechance of survivalofindividualswithend-stage liver disease, transplant patients face many psychological problems such as anxiety, depression, stress $(1,2)$. In a study conducted by Yıldız, it was determined that $57.6 \%$ of patients with liver transplantation experienced moderate trait anxiety (2). In addition, it has been reported that $3 \%$ to $58 \%$ of liver transplant patients experience depressive symptoms and psychological problems are at higher levels in the first few years following organ transplantation $(4,5)$. It is stated that changes in life and roles, potential complications such as infection, organ rejection, social isolation, and steroid and/or immunosuppressive drugs used in the post-transplant period have a significant effect on emerging psychological symptoms (2). It is emphasized that this prevalence of psychological symptoms may cause problems such as insomnia and deterioration in quality of life, and therefore, transplant outcomes are negatively affected $(3,4)$.

Although there are various medical and psychiatric methods in the solution of psychological problems, nondrug methods such as Neuro Linguistic Programming (NLP) have also started to attract attention in recent years (6-8). NLP is a method that allows the individual to change the neural programming of any situation or emotional perception with various techniques and is similar to bodymind therapies in this respect. The term neurological means that all behavior results from the neurological processing of information provided by the five senses. The linguistic part of the title refers to the fact that language is the basis for the organization of thoughts and communication. The term programming expresses that, ideas and behaviors can be changed and managed to create desired results $(3,4)$. NLP allows one to decipher the origin of individual words and speech. In this way, people can feel, think, speak, and thus manage themselves $(6,9)$. When the usage areas of NLP are examined, there are studies examining the effects of many factors such as pain, stress, anxiety, depression, alcohol use, and it is seen that it has positive effects $(6,10-14)$.

Since nurses are health professionals who spend the longest time with patients, they should monitor patients both physiologically and psychologically, develop and implement strategies to solve the problems they detect, as well as before and during the organ transplant process $(15,16)$. When the literature was examined, no study was found that examined the effects of NLP on depression, anxiety, and stress levels in liver transplant patients. In the light of this information, this study was conducted to determine the effect of NLP on the depression, anxiety, and stress levels of patients who had liver transplantation in the last two years.

\section{Hypotheses of the Study}

$\mathbf{H}_{\mathbf{0}}$ : In patients who have had a liver transplant; NLP application does not affect patients' anxiety, depression, and stress levels.

H1: In patients with liver transplant; NLP application affects the anxiety, depression and stress levels.

\section{MATERIAL AND METHOD}

\section{Objective and Type of the Study}

This study was carried out using a prospective randomized single-blind clinical trial model to examine the effects of NLP applications on depression, anxiety, and stress in liver transplant patients.

\section{Time and Place}

This study was conducted with liver transplant patients at a university's Liver Transplant Institute between June 2021 and December 2021.

\section{Population and Sample}

The population of the study consisted of patients who had liver transplant at the mentioned liver transplant institute. The sample size was determined by power analysis. According to the calculation made using $\mathrm{G}$ *power 3.1 software, the sample size was determined as 84 (Experimental group: 42, control group: 42) with 0.40 effect size, 0.05 margin of error, 0.95 confidence level, and 0.90 population representation power. The adequacy of the number of participants was tested by power analysis. Simple random sampling method, one of the probability sampling methods, was used to determine the participants. Participants were selected on a voluntary basis. Random. org program was used to assign participants to groups and assignments were made to groups. Considering possible losses, data collection was started with 103 people.

\section{Inclusion Criteria}

Patients who had moderate and severe depression, anxiety, and stress levels, who were verbally communicative, had no hearing problem, had not practiced NLP before, had no psychiatric disease other than anxiety, depression, and stress, and have passed max 2 years since the transplant were included in the study.

\section{Exclusion Criteria}

Patients who could not communicate verbally, who wanted to leave at any stage of the study, and who had organ rejection were excluded from the sample.

\section{Data Collection Instruments}

Personal Information Form and Depression Anxiety Stress Scale (DASS-21) were used to collect data.

\section{Personal Information Form}

This form, which was prepared by the researchers using the literature, consists of 12 questions (age, gender, education 
level, marital status, economic status, occupation, presence of another disease, time passed after transplant, place of residence, previous diagnosis of depression or anxiety disorder the number of years of liver disease in the preoperative period, the existence of a method used to cope with depression, anxiety and stress in daily life) $(1,2,5,7)$.

Depression Anxiety Stress Scale - 21 Items (DASS-21): The Depression Anxiety Stress Scale -DASS, developed by Lovibond \& Lovibond in 1995, consists of 42 questions. The original DASS contains 42 self-report items that reveal three components of negative emotional states: Depression (DASS-Depression), Anxiety (DASS-Anxiety), and Stress (DASS-Stress). The validity and reliability of a short version of the measurement has been validated by Antony et al. (1998). The short form DASS-21 consists of 21 self-report questions graded on a four-point scale to indicate severity and severity. It consists of questions about symptoms experienced in the past week. In this scale (DASS-21), there are 7 questions each to measure the dimensions of depression, stress and anxiety. The first 7 items of the scale include questions about anxiety, the second 7 items about depression, and the third 7 items about stress. Three subscales, each consisting of seven items, and the scores of each dimension contain related questions. The scale is a 4-point Likert Type Scale and was coded as: 0 "Did not apply to me at all", 1 "Applied to me to some degree, or some of the time", 2 "Applied to me to a considerable degree or a good part of the time", and 3 "Applied to me very much or most of the time". The Turkish validity and reliability study was conducted by Yıldırım et al. DASS-21 subscales were found to be DASS-Depression $a=0.89$, DASS-Anxiety $a=0.87$, and DASS Stress $a=$ $0.90(17,18)$. In this study, the Cronbach's alpha value obtained for the DASS-21 scale was found to be 0.866 for the experimental group and 0.784 for the control group. The Cronbach's alpha value for the depression subscale was 0.773 for the experimental group and 0.808 for the control group. The Cronbach's alpha value for the anxiety sub-dimension was 0.726 for the experimental group and 0.458 for the control group. The Cronbach's alpha value for the stress sub-dimension was 0.753 for the experimental group and 0.587 for the control group.

\section{Data Collection}

Data were collected between 1 July and 30 October. Telephone numbers of patients who had liver transplantation in the last 2 years were obtained from hospital records. The patients were randomly called by the researcher by telephone. After they were informed about the study by telephone and their verbal consent was obtained, the DASS-21 scale was applied. After applying the Personal Information Form and DASS-21 to the patients in the experimental group, the sub-modality technique of NLP was applied once (19). Afterwards, NLP was applied 4 times in total, with one-week intervals. After
28 days, the last NLP application was made, and DASS21 has applied again. The patients in the control group were informed about the study in the first phone call, the Personal Information Form and DASS-21 were applied after their consent was obtained, the patients were called again 28 days later, and DASS-21 was applied for the second time. No intervention was made in the control group. The application of the Personal Information Form and DASS21 took an average of 10-15 minutes for each patient, and each NLP application took approximately 30 minutes.

\section{Evaluation of the Data}

Data analysis was performed with SPSS (Statistical Program in Social Sciences) 25 software. Whether the data fit the normal distribution was checked with the Sahapiro Wilk Test. The significance level (p) for the comparison tests was taken as 0.05 . Since normal distribution was achieved in the variables $(p>0.05)$, the analysis was continued with parametric test methods. Since the assumption of normality was ensured in the comparisons in dependent pairs, the significance test of the difference between the two pairs (two paired samples t test) was performed. In repeated measurements, analysis of variance (repeated measure of ANOVA) was used to test whether there was a difference between groups. Multiple normal distribution and homogeneity of variance were controlled in the analyses. Analysis of variance on repeated measures is a generalized form of the test of significance between two peers for more than two groups. This method differs from one-way analysis of variance in independent groups, as it provides the opportunity to examine changes over time. In repeated measures, two-way ANOVA analysis is used in cases where there are repetitions on one of the factors. In these trials, for example, while groups are the first factor, the second factor is time. There are repeated measurements on time, which is one of the factors. The aim here is to test whether the change in the dependent variable according to time differs between the experimental and control groups (20). As a result of the analysis, both within-group and between-group changes according to time can be compared, and at the same time, while the $\mathrm{HO}$ hypothesis is true, the probability of rejection (Type I error) will decrease, and consistent results will be obtained (21).

\section{Ethical Aspect of the Study}

Institutional permission and ethics committee permission were obtained from the relevant university in order to conduct the research (Decision Number: 2021/2063). Verbal consent was obtained from the patients participating in the study.

\section{RESULTS}

It was tested whether there was a difference between the groups according to the demographic variables of the participants included in the study and the results are given in Table 1 below.

No statistically significant difference was found between 
the experimental and control groups according to the variables of gender, marital status, economic status, occupation, additional disease status, and place of residence ( $p>0.05$, Table 1$)$. A statistically significant difference was found between the experimental and control groups according to the educational status of the participants and a method used to cope with depression, anxiety, and stress ( $p<0.05$, Table 1$)$.

It was tested whether there was a difference between the groups according to the demographic variables of the patients included in the study and the results are given in Table 2 below.

There was no statistically significant difference between the experimental and control groups according to the variables of age and time elapsed after transplantation in the patients included in the study ( $p>0.05$, Table 2$)$. A statistically significant difference was found between the experimental and control groups according to the duration of the disease in the patients included in the study $(p<0.05$, Table 1).

Table 1. Comparison of the groups by distribution of demographic variables

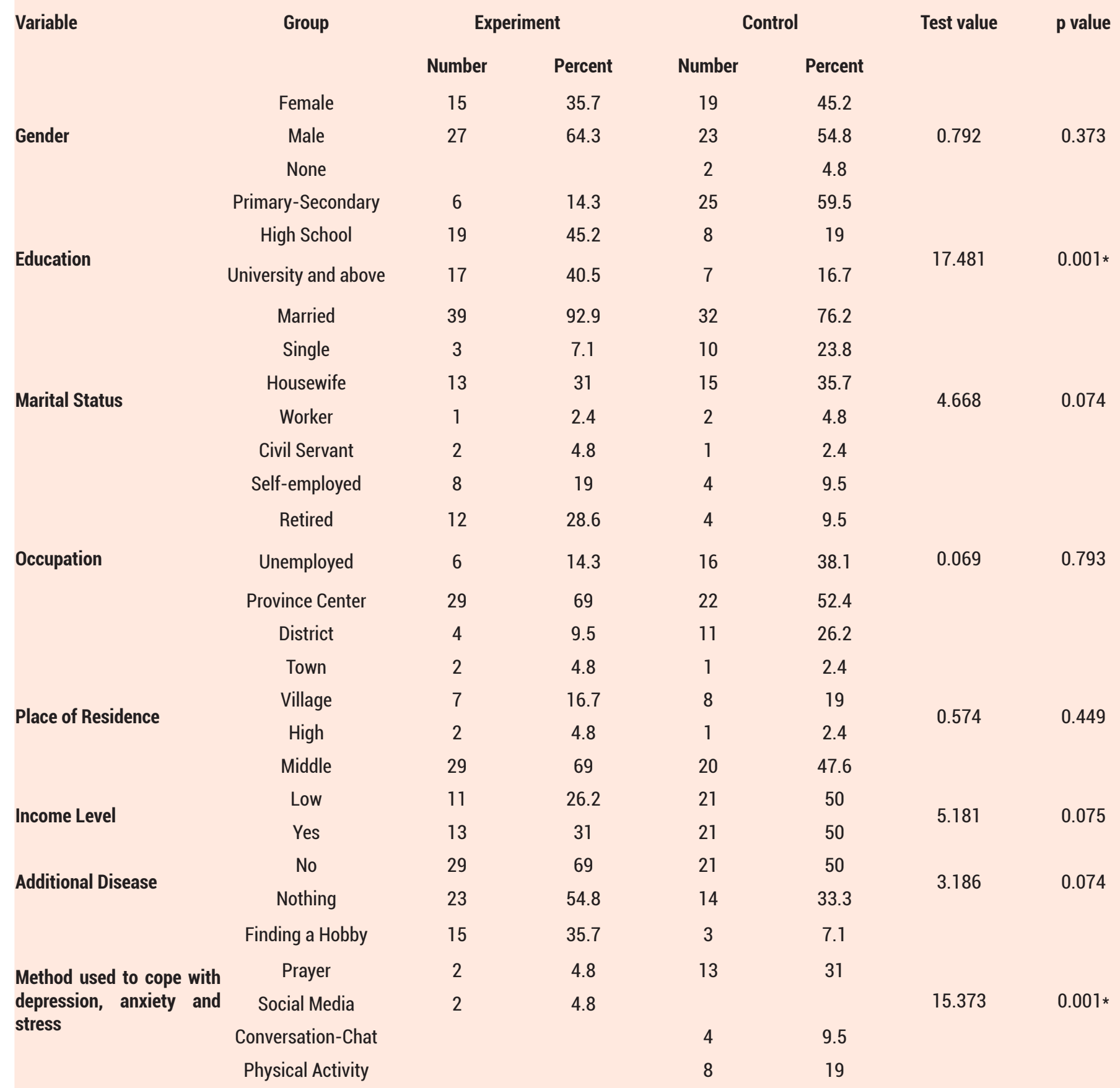

Test value; Chi-square Test value ( $\chi 2$ ), p value; statistical significance 
Table 2. Comparison of the groups by distribution of demographic variables

$\begin{array}{lcccc}\text { Variable } & \text { Group } & \text { Mn } \pm \mathbf{s d} & \text { Test value } & \text { p value } \\ \text { Age } & \text { Experiment } & 50.1 \pm 12.14 & \mathbf{0 . 9 0 3} & \mathbf{0 . 3 6 9} \\ & \text { Control } & 47.43 \pm 14.79 & -3.129 \\ \text { Duration of the Disease } & \text { Experiment } & 4.76 \pm 4.84 & 0.002 * & 0.627 \\ & \text { Control } & 15.38 \pm 6.56 & 0.532 \\ \text { Time after transplant (Month) } & \text { Experiment } & 14.4 \pm 7.66 & & \end{array}$

It was tested whether the depression, anxiety, stress, and DASS-21 scores of the participants included in the study changed according to time both within and between groups (experimental and control), and the results are given in Table 3.

In the measurement made, it was observed that while there was a decrease in the depression score in the experimental group, there was an increase in the control group.

For Depression; Depression in the experimental group was statistically significant as the value obtained in the second measurement was lower than the value obtained in the first measurement $(p<0.05$, Table 3$)$. In the control group, the value obtained in the second measurement for depression was found to be higher than the value obtained in the first measurement, which was statistically significant $(p<0.05$, Table 3$)$. It was found statistically significant that the changes in depression scores between the first measurement and the second measurement according to time in the patients included in the study differed between the experimental and control groups $(p<0.05$, Table 3$)$. Changes in time difference explain $50.7 \%(\boldsymbol{y}=0.507)$ of the variation between measurements with groups. The interaction graph of depression measurements is given below;

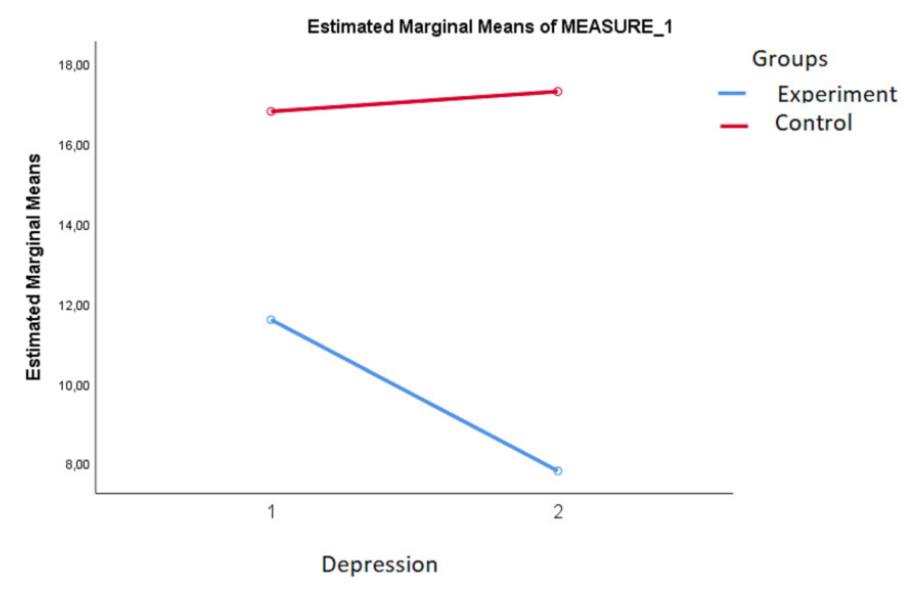

Figure 1. Distribution of depression measurements over time in groups

For Anxiety; In the experimental group, the value obtained in the second measurement of anxiety was found to be lower than the value obtained in the first measurement, which was statistically significant $(p<0.05$, Table 3$)$. In the control group, it was statistically significant that the value obtained in the second measurement of anxiety was higher than the value obtained in the first measurement $(p<0.05$, Table 3$)$. It was found statistically significant that the changes in anxiety scores between the first measurement and the second measurement according to time in the patients included in the study differed between the experimental and control groups $(p<0.05$, Table 3$)$. Changes in time difference explain $50.7 \%(\boldsymbol{y}=0.507)$ of the variation between measurements with groups. The interaction graph of anxiety measurements is given below;

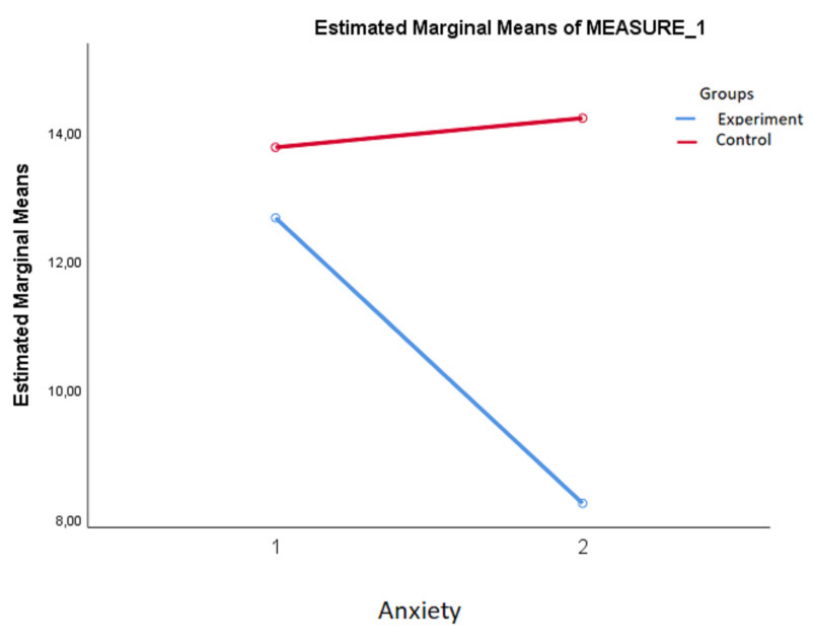

Figure 2. Distribution of anxiety measurements over time in groups

In the measurement made, it was observed that while there was a decrease in the anxiety score in the experimental group, there was an increase in the control group.

For Stress; The fact that the value obtained in the second measurement of stress in the experimental group was lower than the value obtained in the first measurement was found to be statistically significant $(p<0.05$, Table 3 ). It was found statistically significant that the value obtained in the second measurement of stress in the control group was higher than the value obtained in the first measurement $(p<0.05$, Table 3$)$. It was found statistically significant that the changes in the stress score between the first and second measurements over time in the patients included in the study differed between the experimental and control groups $(p<0.05$, Table 3$)$. Changes in time difference explain $50.7 \%(\boldsymbol{\eta}=0.507)$ of the variation between measurements with groups. The interaction graph of stress measurements is given below; 


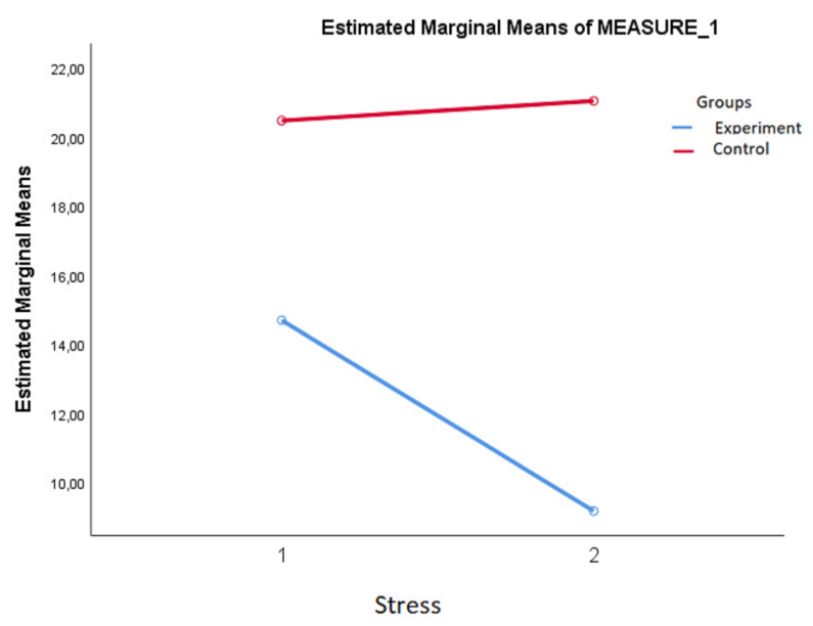

Figure 3. Distribution of stress measurements over time in groups

In the measurement made, it was observed that while there was a decrease in the stress score in the experimental group, there was an increase in the control group.

For DASS-21; The fact that the value obtained in the second measurement of DASS in the experimental group was lower than the value obtained in the first measurement was found to be statistically significant $(p<0.05$, Table 3$)$. It was found statistically significant that the value obtained in the second measurement of DASS in the control group was higher than the value obtained in the first measurement $(p<0.05$, Table 3$)$. It was found statistically significant that the changes in the DASS score between the first and second measurements in terms of time in the patients included in the study differed between the experimental and control groups $(p<0.05$, Table 3$)$. Changes in time difference explain $50.7 \%(\boldsymbol{y}=0.507)$ of the variation between measurements with groups. The interaction graph of DASS-21 measurements is given below;

In the measurement made, it was observed that while there was a decrease in the DASS score in the experimental group, there was an increase in the control group.

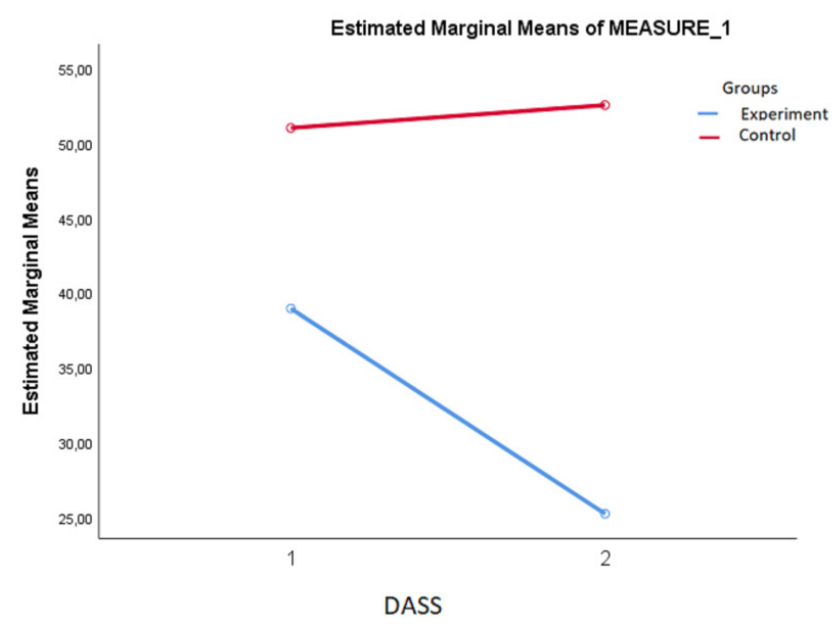

Figure 4. Distribution of DASS measurements over time in groups

Table 3. Intra-group and inter-group comparison of measurement scores

\begin{tabular}{|c|c|c|c|c|c|c|c|c|}
\hline \multirow{2}{*}{ Variable } & \multirow[t]{2}{*}{ Group } & \multirow[t]{2}{*}{ Measurement } & \multirow[t]{2}{*}{$M n \pm s d$} & \multicolumn{2}{|c|}{ Intra-Group } & \multicolumn{2}{|c|}{ Inter-Group } & \multirow[b]{2}{*}{$\eta(E t a)$} \\
\hline & & & & t value & $p_{1}$ value & F value & p2 value & \\
\hline \multirow{3}{*}{ Depression } & & Before & $11.6 \pm 4.21$ & & & \multirow{3}{*}{84.341} & \multirow{3}{*}{0.001 * } & \multirow{3}{*}{0.507} \\
\hline & \multirow{2}{*}{ Control } & Before & $16.81 \pm 4.41$ & \multirow{2}{*}{-3.344} & \multirow{2}{*}{0.002 ** } & & & \\
\hline & & After & $17.31 \pm 4.37$ & & & & & \\
\hline \multirow{3}{*}{ Anxiety } & Experiment & After & $8.24 \pm 2.02$ & 9.736 & 0.001 ** & \multirow{3}{*}{26.704} & \multirow{3}{*}{$0.001 *$} & \multirow{3}{*}{0.246} \\
\hline & \multirow[b]{2}{*}{ Control } & Before & $13.76 \pm 3.31$ & \multirow{2}{*}{-2.756} & \multirow{2}{*}{$0.009 * *$} & & & \\
\hline & & After & $14.21 \pm 3.24$ & & & & & \\
\hline Stress & Experiment & Before & $14.69 \pm 4.73$ & 12.804 & $0.003 * *$ & 168.627 & 0.001 * & 0.673 \\
\hline \multirow{4}{*}{ DAS } & \multirow[t]{2}{*}{ Experiment } & Before & $\begin{array}{c}38.95 \pm \\
11.96\end{array}$ & 11.928 & $0.001 * *$ & & & \\
\hline & & After & $25.21 \pm 5.43$ & & & 125006 & * & $06 \Omega 4$ \\
\hline & Control & Before & $51.05 \pm 7.53$ & -4078 & $\cap \cap 0 \cap 1$ ** & 120.050 & & \\
\hline & & & $52.57 \pm 7.92$ & & $0.001^{\pi x}$ & & & \\
\hline
\end{tabular}

$\mathrm{Mn}$; mean. sd; standard deviation, p1 Value; intra-group comparison significance test result, p2 Value; ANOVA significance test result in repeated measures between groups, ; Eta value $* \mathrm{p}<0.05$ There is a statistically significant difference between intra-group measurements. $* \star p<0.05$, there is a statistically significant difference between the groups 


\section{CONSORT 2010 Flow Diagram}

\section{Enrollment}

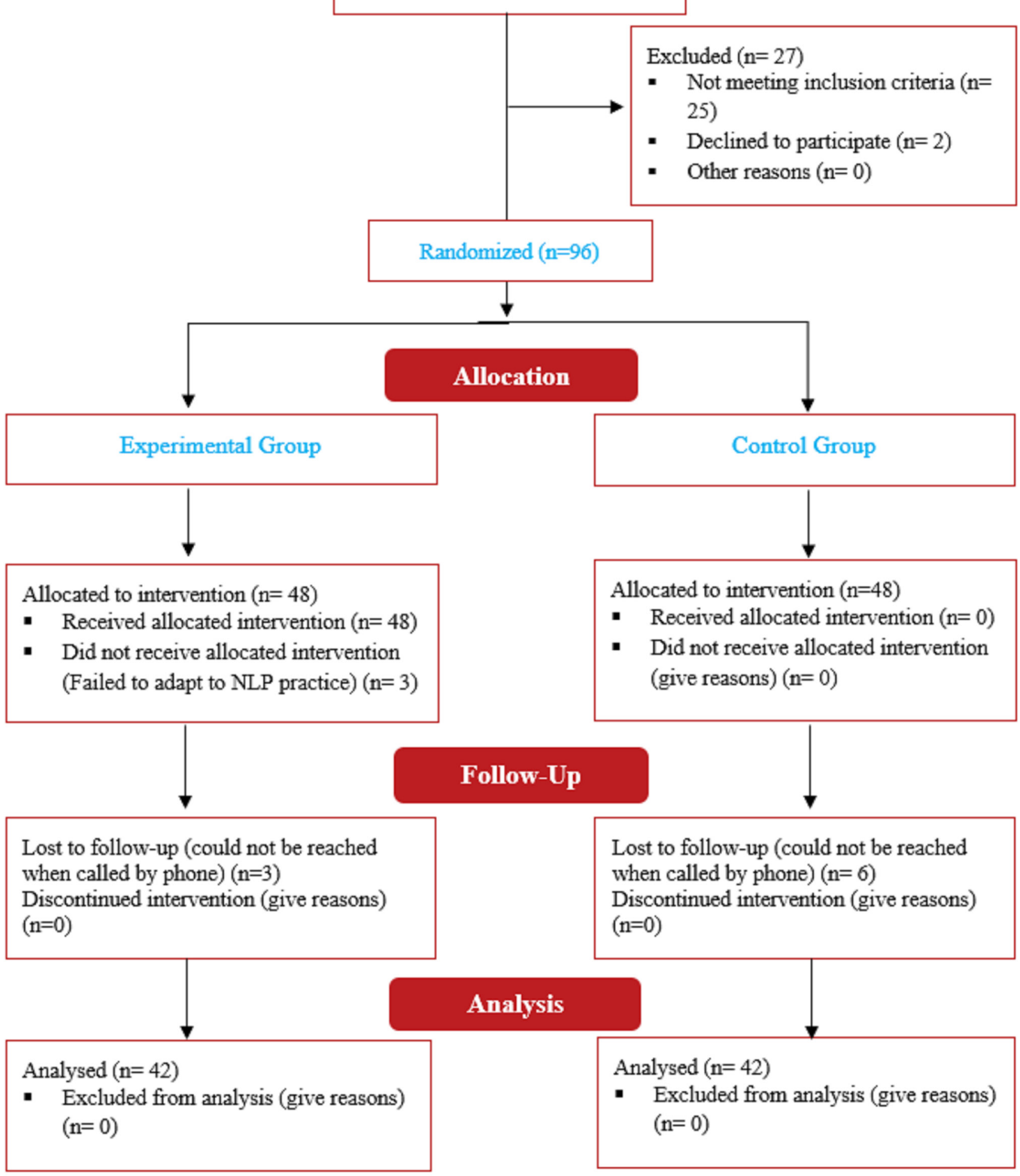

\section{DISCUSSION}

Many psychological symptoms are seen after liver transplantation $(1,2,4,5)$. These symptoms lead to many important problems such as treatment and drug noncompliance, insomnia, deterioration in the quality of life, and increase morbidity and mortality rates $(3,4)$. In this study, it was determined that $54.8 \%$ of the experimental group patients and $33.3 \%$ of the control group patients have given the answer "nothing" to the question of "Is there a method you use to deal with depression, anxiety, 
and stress in your daily life?" However, the management of psychological symptoms after liver transplantation is extremely important in terms of causing the abovementioned problems (3-5). Nurses and other health professionals should monitor patients both physiologically and psychologically and develop and implement strategies to solve the problems they detect, as well as before and during liver transplantation $(15,16)$. When the literature is examined, NLP draws attention among the strategies that can be developed for psychological symptoms $(6-8,10,11)$.

Although patients with moderate and severe levels of depression, anxiety, and stress were included in the experimental and control groups in this study, when other studies are examined, it is seen that liver transplant patients experience significant depression, anxiety, and stress $(2,5,22)$. In a study by Mendes et al., it was determined that more than half of the liver transplant patients experienced moderate anxiety, and close to 10 percent had high-level anxiety. It was found that nearly $40 \%$ of the same patient group experienced high levels of stress (5). In the study conducted by Yıldız, it was determined that more than half of the patients experienced state anxiety (2). In another study, it was determined that $57.8 \%$ of the patients who had a liver transplant one month ago and $75.0 \%$ of the patients who had one year passed were depressed (22).

The findings of this study show that NLP statistically significantly reduced the depression, anxiety, and stress scores of liver transplant patients and the total DASS-21 score $(p<0.05)$. In the control group, it was determined that the mean DASS-21 score increased in the second measurement $(p<0.05)$. When the literature was examined, no study was found that examined the effect of NLP on depression, anxiety, or stress levels in liver transplant patients, but it was seen that there were many studies conducted in different groups (23-25). In two studies conducted with individuals and students with posttraumatic stress disorder, it was found that NLP reduced both depression, anxiety, and stress levels; In another study conducted with athletes, it was seen that the DASS-21 scale was used and NLP reduced the stress level (23-25). In another study, it was determined that NLP application reduced social anxiety in individuals who applied to a counseling center (26). In this study, the sub-modality technique was used in the interviews made using NLP techniques. In this study, based on the principle that nurses use the patient's potential at the highest level while giving care, the principle of "people have the resources they need", one of the NLP assumptions, was used. NLP practices and goal-setting studies focused on the resources to be used to reach the desired state from the current situation, and awareness of their resources was created in patients (2729). Thanks to NLP studies, patients found the courage and ability to cope with negative emotions, felt strong to reach the goals they set and decreased depression, anxiety, and stress. The fact that the DASS-21 average score of the control group increased as a result of the research is quite remarkable and shows the importance of developing strategies for depression, anxiety, and stress.

\section{CONCLUSION}

In this study, NLP intervention was found to reduce depression, anxiety, and stress in liver transplant patients. In line with these results, it can be recommended that nurses closely monitor their patients' symptoms such as depression, anxiety, and stress both during their hospitalization and after discharge. It may also be recommended to create an individualized care plan specific to each patient, to benefit from non-pharmacological strategies such as NLP in the management of some psychological symptoms, and/or to receive training on this subject. In addition, it may be recommended to conduct studies in different patient groups.

\section{Contributions of the Study to Nursing}

In this study, it was observed that the NLP sub-modality technique applied to patients who underwent liver transplantation and had moderate to high anxiety, depression, and stress levels contributed to reducing anxiety, depression, and stress levels to a tolerable level. The nurse aims to provide individualized care in the nursing process. In NLP techniques, the individual is evaluated with his own values and his view of the problem is made positive. NLP techniques are compatible with the nursing process with this aspect. Nurses learning NLP techniques and guiding patients on this issue will strengthen individualized care.

\section{Strengths and limitations of the study}

The study was carried out with patients who had liver transplantation in the same center living in many different cities of Turkey. Its strength is that it was carried out online with individuals with high anxiety during the pandemic process. Since it cannot be done face-to-face, the compliance of the patients is limited to the patient statement. This is the limitation of the research.

Financial disclosures: All authors report no financial interests or potential conflicts of interest. .

Conflict of Interest: The authors declare that they have no competing interest.

Ethical approval: Institutional permission and ethics committee permission were obtained from the relevant university in order to conduct the research (Decision Number: 2021/2063). Verbal consent was obtained from the patients participating in the study.

\section{REFERENCES}

1. Zhu X, Ming Y, Liu J, et al. Sleep quality and psychosocial factors in liver transplant recipients at an outpatient follow-up clinic in China. Annals of Transplantation. 2020;25:e920984-1-e920984-8.

2. Yıldız E. The relationship between anxiety and ıntolerance of uncertainty levels in Individuals who received liver transplant: a descriptive cross-sectional study. Clinical Nursing Research. 2021;30:548-57. 
3. García-Alanís M, Toapanta-Yanchapaxi L, Vilatobá $M$, et al. Psychosocial evaluation for liver transplantation: a brief guide for gastroenterologists. Revista de Gastroenterología de México (English Edition). 2021;86:172-87.

4. Annema C, Drent G, Roodbol PF, et al. Trajectories of anxiety and depression after liver transplantation as related to outcomes during 2-year follow-up: a prospective cohort study. Psychosomatic Medicine. 2018;80:174-83.

5. Mendes KDS, Lopes ARF, Martins TA, et al. Relevance of anxiety and stress levels on sleep quality after liver transplantation. Transplantation Proceedings. 2014;46:1822-6.

6. HemmatiMaslakpak M, Farhadi M, Fereidoni J. The effect of neuro-linguistic programming on occupational stress in critical care nurses. Iranian J Nursing Midwifery Res. 2016;21:44

7. Kotera Y, Sheffield D, Van Gordon W. The applications of neuro-linguistic programming in organizational settings: a systematic review of psychological outcomes. Human Resource Development Quarterly. 2019;30:101-16.

8. Kotera Y, Van Gordon W. Japanese managers' experiences of neuro-linguistic programming: a qualitative investigation. Journal of Mental Health Training, Education and Practice. 2019;14:174-85.

9. Doğan A, Saritaş $S$. The effects of neuro-linguistic programming and guided imagery on the pain and comfort after open-heart surgery. J Cardiac Surg. 2021;36:2389-97.

10. Kotera Y, Sheffield D. NLP for Japanese workers' mental wellbeing: pilot study. Mental Health Review J. 2019;24:183-94.

11. Sheoran P. Effectiveness of NLP in dealing with guilt Induced anxiety, depression and stress: a case study. In: Makvana S, Patel A, Dhingra A, Parmar V, editors. Mental Health: A Journey from illness to wellness. İndia; 2016. p. 179-88.

12. Karmen $C$, Hsiung RC, Wetter T. Screening internet forum participants for depression symptoms by assembling and enhancing multiple NLP methods. Computer Methods and Programs in Biomedicine. 2015;120:27-36.

13. Nompo RS, Pragholapati A, Thome AL. Effect of neurolinguistic programming (NLP) on anxiety: a systematic literature review. KnE Life Sciences. 2021;496-507.

14. Kim H, Bae J. Development and evaluation of group counseling program using neurolinguistic programming for alcoholics. Journal of Korean Academy of Psychiatric and Mental Health Nursing. 2018;27:98-109.

15. Kaçmaz $\mathrm{N}$. The psychsocial status of liver transplant patient and their relatives on the effect of quality of life. Marmara Universitiy; 2011.

16. Temiz G, Kaya A. Psychosocial problems and nursing approach to volume after kidney transplantation. Journal of Nephrology Nursing. 2017;2:1-6.
17. Antony MM, Cox BJ, Enns MW, et al. Psychometric properties of the 42-item and 21-item versions of the depression anxiety stress scales in clinical groups and a community sample. Psychological Assessment. 1998;10:176-81.

18. Yıldırım A, Boysan M, Kefeli MC. Psychometric properties of the turkish version of the depression anxiety stress scale-21 (DASS-21). British Journal of Guidance \& Counselling. 2018;46:582-95.

19. Bandler R, Grinder J. NLP use your brain for change: neurolinguistic programming. 5th Edition. Turkish translation: Akinhay O, editor. Istanbul: Alfa Publications; 2016.

20. Alpar R. Applied statistics and validity-reliability with examples in sports, health and educational sciences. 6th Edition. Ankara: Detay Publishing; 2020.

21. KaragözY.SPSS and AMOS applied, qualitative- quantitativemixed scientific research methods and publication ethics. Istanbul: Nobel Publishing; 2021.

22. Pelgur $\mathrm{H}$, Atak N, Kose K. Anxiety and depression levels of patients undergoing liver transplantation and their need for training. Transplantation Proceedings. 2009;41:1743-8.

23. Wake $L$, Leighton $M$. Pilot study using neurolinguistic programming (NLP) in post-combat PTSD. Mental Health Review Journal. 2014;19:251-64.

24. Hendriana D, Komarudin K, Mulyana RB. The application of neuro linguistic programming (NLP) on cognitive function and stress reduction. Competitor: Jurnal Pendidikan Kepelatihan Olahraga. 2021;13:247-61.

25. Anjomshoaa H, Snagui-Moharer G, Shirazi M. Comparing the effectiveness of training cognitive behavioral therapy and neuro-linguistic programming strategies on enhancing resilience of high school students in Kerman, Iran. International Journal of Pediatrics. 2020;8:11877-89.

26. Abdivarmazan $M$, Sylabkhori Z. Effectiveness of training of neuro-linguistic programming (NLP) strategies on reducing social anxiety. World Scientific News. 2016;60:67-77.

27. Passmore J, Rowson TS. Neuro-linguistic-programming: a critical review of NLP research and the application of NLP in coaching. International Coaching Psychology Review. 2019;14:57-69.

28. Carriere J, Shafı H, Brehon K, et al. Case Report: Utilizing Al and NLP to assist with healthcare and rehabilitation during the COVID-19 pandemic. Frontiers in Artificial Intelligence. $2021 ; 4$.

29. Potter PA, Perry AG, Stockert PA, Hall AM, editors. Fundamentals of nursing. Pennsylvania: Elsevier; 2017. 